\title{
Do Indonesian Islamic Microfinance Institutions Need Lender of the Last Resort?
}

\author{
Imron Mawardi ${ }^{1 *}$, Tika Widiastuti ${ }^{2}$, Muhammad Ubaidilah Al Mustofa ${ }^{3}$, \\ Ari Prasetyo ${ }^{4}$ \\ 1,2,3,4 Department of Islamic Economics, Faculty of Economics and Business, \\ UniversitasAirlangga, Jalan Airlangga, Gubeng, Surabaya 60286, Indonesia
}

\begin{abstract}
Liquidity risk is one of significant risk managed by financial intermediaries including Islamic Microfinance Institutions (IMFIs). The financial intermediaries accept short-term deposits and disburse these deposits in the form of long-term loans. This situation makes IMFI desperately need a lender of last resort (LOLR). Nevertheless, there has been no formal LOLR for Indonesian IMFIs. This study intends to construct the LOLR model for IMFI in Indonesia. This qualitative study applies a case study analysis. This study's subjects are IMFIs in East Java Province that was selected purposively with thirty managers as the key informants. Research findings show that the best model of LOLR is developing a secondary cooperative since the majority form of IMFIs in Indonesia are cooperative entities. With all members of a secondary cooperative deposit for reserve requirements, they can place excess liquidity in the secondary cooperative and ask for financial support.
\end{abstract}

Keywords: Islamic Microfinance Institution; Islamic Cooperatives; Lender of the Last Resort; Liquidity

Paper type: Research paper

*Corresponding author: ronmawardi@feb.unair.ac.id

Received: May 26, 2020; Accepted: Juny 26, 2020; Published: July 01, 2020

Cite this document: Mawardi, I., Widiastuti, T., Al Mustofa, M. U., Prasetyo, A. (2020). Do Indonesian Islamic Microfinance Institutions Need Lender of the Last Resort?. AlUqud: Journal of Islamic Economics, 4(2), 235-249. doi: http://dx.doi.org/10.26740/aluqud.v4n2.p235-249

Copyright () 2020, Al-Uqud: Journal of Islamic Economics http://journal.unesa.ac.id/index.php/jie 


\begin{abstract}
Abstrak: Risiko likuiditas adalah salah satu risiko signifikan yang dikelola oleh perantara keuangan termasuk Islamic Microfinance Institutions (IMFIs). Perantara keuangan menerima simpanan jangka pendek dan mencairkan simpanan ini dalam bentuk pinjaman jangka panjang. Situasi ini membuat IMFI sangat membutuhkan lender of last resort (LOLR). Namun demikian, belum ada LOLR formal untuk IMFI Indonesia. Studi ini bermaksud untuk membangun model LOLR untuk IMFI di Indonesia. Penelitian kualitatif ini menggunakan analisis studi kasus. Subjek penelitian ini adalah IMFI di Provinsi Jawa Timur yang dipilih secara purposif dengan tiga puluh manajer sebagai informan kunci. Temuan penelitian menunjukkan bahwa model terbaik LOLR adalah mengembangkan koperasi sekunder karena mayoritas bentuk IMFI di Indonesia adalah entitas koperasi. Dengan semua anggota mendepositokan di koperasi sekunder untuk persyaratan cadangan, mereka dapat menempatkan kelebihan likuiditas di koperasi sekunder dan meminta dukungan keuangan.
\end{abstract}

Kata kunci: Lembaga KeuanganMikro Syariah; Koperasi Syariah; Lender of the Last Resort; Likuiditas.

\title{
INTRODUCTION
}

High rates of poverty and income inequality remain significant issues in the world economy. One of the recommendations for overcoming poverty and inequality from various organisations is through a financial inclusion system. Increasing financial inclusion is believed to reduce poverty and inequality. Expanding public access to the formal financial sector will help people improve their incomes as part of poverty alleviation strategies.A microfinance institution (MFI) is an intermediary financial institution that helps provide financial aid for the poor to improve their household welfare and reduce poverty.Another goal of an MFI is to reduce the income gap between the riches and the poor. Formal financial institutions such as banks usually demand requirements such as collateral and income statement, before granting credit. The collateral acts as a guarantee and could be in the form of a certificate of ownership for lands, houses, properties, and cars. The rural poor are not bankable, as they face a difficult obstacle to provide the specific requirements demanded by the banks. Thus, banks become reluctant to give financial supports to the poor. Access to finance is essential, and it is used to provide better education, health service, and decent housing for the poor (Berhane \& Gardebroek, 2011; Fianto et al., 2018; Littlefield et al., 2003).

The financial instruments offered by Islamic microfinance institutions fulfil the needs and demands of the community. Eventually, the sharia-compliance instruments provided help improve the welfare of the Muslim community and highly reduce the extent and the severity of poverty. (Abbas \& Shirazi, 2015;Adnan \& Ajija, 2015).For very low-income families, saving is very expensive. The low income can only make the fundamental consumption and necessities at their minimum level; thus, Islamic micro-financing plays an essential role in improving the family's well-being (Hassan \& Saleem, 2017). The Degree of Islamic financing to support poverty alleviation will be higher if it is conducted in many areas throughout the country and legally supported by the central government through laws and regulations (Hadisumarto \& Ismail, 2010). 
Imron Mawardi, Tika Widiastuti, Muhammad Ubaidilah Al Mustofa, Ari

Prasetyo: Do Indonesian Islamic Microfinance Institutions Need Lender of the Last Resort?

There are several reasons big financial intermediaries, such as banks, are reluctant to provide loans or capital assistance to support the business of the poor. First, poor people have no collateral needed to guarantee the loans. Second, poor people often have no stable income to support the repayment of the loans. Third, the high administrative cost for the banks, since poor people will only take a small value of credits, thus making the administrative burden increase (Abdullah \& Ismail, 2014). IMIFs focus on equity financing that promotes profit and loss sharing (PLS) business activities. In contrast, the conventional financial intermediaries, such as conventional banks, conventional cooperations, unevenly distribute risk and return. The conventional method in favour of the capital owners by making the poor borrower work for their benefits (Rahman \& Dean, 2013).

According to Asosiasi BMT Seluruh Indonesia/ABSINDO (2019), the development of Islamic Microfinance Institutions (IMFIs) is seen to be overgrowing. Since the first establishment in 1990, the number of operating IMFIs has reached 6,051 in 2016. However, this number decreased in 2019 to reach only 5.806 IMFIs. There are 245 IMFIs stopped operating in the last three years. Islamic Microfinance institutions (IMFI) are an intermediary financial institution for the micro sector that applies Islamic principles. More than $98 \%$ of IMFIs in this country operates as Islamic cooperatives, under the law of Minister of Cooperatives and SMEs No. 91 in 2004. IMFIs obtain short-term funds from the members and release them in the form of financing, usually for long-term. The mismatch period between deposits and financings make these institutions inherently vulnerable to liquidity problems, which is more commonly known as liquidity risk.

Islamic microfinance institutions provide financial solutions for not bankable people and could not access financial supports from banks or other formal financial institutions that provide interest-based financing. IMFIs are financial institutions that operate with Islamic values and principles (Fianto et al., 2019). In Indonesia, IMFIs arecommonly known as Baitul Maal wat Tamwil (BMT), Baitul Tamwil, Islamic cooperative (Koperasi Syariah), Islamic financial services cooperatives (Koperasi Jasa Keuangan Syariah/KJKS), and Credit Union and Islamic Financing (Koperasi Simpan Pinjam Pembiayaan Shariah/KSPPS).

IMFIs have unique characteristics, both in terms of funding and financing. In terms of funding, most of the deposits use Mudharaba contract, which is an uncertain contract. The depositors as ShohibulMaal (those who provide capitals) conduct an agreement with IMFI as Mudhorib (an entity with economic activities). Both parties share the rate of profit and loss, which cannot be fixed and based on financial performance. On the financing side, IMFI uses various financing schemes with unique characteristics, including Ijarah and Murobahah contract that make the cash flow of the two parties fixed.

The difference between the deposit and financing schemes make IMFIs face the possibility of a substantial liquidity crisis. Liquidity and profitability are the trade-offs for an intermediary institution. When financial institutions aim to gain immense profits by channelling most of their funds, the cash available decreased. Conversely, if the financial institution was providing substantial funds to maintain 
liquidity, the funds used to provide financing will decrease so that profitability also declined.

The inability of IMFI to pay its obligations will make this institution collapses. As many depositors lost their trusts, the withdrawal of funds cannot be avoided, leading to a rush. The claims of the asset from the depositors provide more pressures to the IMFIs. The failure could also affect other IMFIs and causing liquidity shock in the financial industry. To avoid a liquidity shock, IMFI requires the lender of last resort (LOLR) such that in the institutional banking industries. LOLR is the provision of a loan facility to financial intermediaries experiencing liquidity problem and serves to avert a systemic crisis in the financial industry.

The concept of Lending of Last Resort has developed through many years, starting from Bagehot (1873) to the more modern concept of international Lender of Last Resort developed by Lerrick\& Meltzer (2003), Corsetti et al. (2006) and Bastidon et al.(2008). However, this concept focusses more on rescuing the conventional financial intermediaries such as banks from liquidity problems. To the best authors' bits of knowledge, we found no study has attempted to design Lending of Last Resort's model for IMFIs. In contrast with banks, the government did not provide the lender of the last resort facility for IMFIs. Therefore, many IMFIs establish the LOLR plans as a step to evade the failure in fulfiling obligations, especially payments to depositors who withdraw funds at any time. The need for constructing LOLR mechanism and liquidity products for Islamic financial institutions has been highlighted by (IMF, 2017; Hassan et al., 2019). Even for the Islamic bank industries, the LOLR mechanism and liquidity products still need for more improvements and studies. This study aimed to construct several LOLR models for Indonesian IMFIs. It also builds an ideal model of LOLR under Islamic values. It is one of the first attempts in developing the model of LOLR for Indonesia IMFIs.

\section{Islamic Microfinance Institution}

According to Law No. 1 the year 2013 section 1, a microfinance institution is a financial institution that provides either a loan or financing for small business or micro-enterprises to its members and the public. Microfinance institution has goals to provide business development and community development services. Some microfinance institutions apply Islamic laws, principles, and values in their services and called the Islamic Microfinance Institution (IMFI).

IMFI is an intermediary institution which receives deposits and provides financing with Shariah compliance contracts only to members of the cooperative. As a business organisation that is also social institutions, IMFIs collect and distribute zakat, sadaqah and infaq and manage the waqf property. IMFIs in Indonesia adopted the concept of the Baitul MaalwaTamwil, which runs as a business institution (Baitul Tamwil) and social institutions (Baitul Maal) (Wardiwiyono, 2012). The idea of Baitul Maal means BMT acts as a religious, social institution that has the function to receive zakat, alms, infaq, and waqaf funds and channel them to those who are entitled to receive these funds. Whereas in the Baitul Tamwil concept, BMT has a role as a business and financial institution that aims to seek profit such as opening a convenience store (department store) or offering savings and loan products to the public. BMTs are more likely to act as sharia financial 
Imron Mawardi, Tika Widiastuti, Muhammad Ubaidilah Al Mustofa, Ari

Prasetyo: Do Indonesian Islamic Microfinance Institutions Need Lender of the Last Resort?

institutions providing savings and loan products to the community based on sharia principles. Further, Baitul Tamwilhas operational targets focused on the Small and Medium Enterprises (SME) sector.

The number of IMFIs in Indonesia is experiencing an overgrowing phase. In 2010, 3,307 IMFIs was recorded with total assets equivalent to Rp 3.6 trillion. In 2015, the number of IMFIs had increased to more than 5,000 institutions with assets of more than Rp 4.7 trillion. In 2016, the number reached to more than 6,000 institutions (Ministry of Cooperatives and SMEs). However, this number decreased in 2019 to reach only 5.806 IMFIs. Many IMFIs have branches to provide services to members and the community in various villages and towns.

As business organisations, IMFIs runs financial intermediation function. IMFIs receive deposits in the form of savings, compulsory savings, voluntary savings, and other savings equated with mandatory savings with sharia contract. The contracts used are wadiah and mudharaba. IMFIs provide financing services usingShariah compliance contract, including murabaha, salam, istishna, Ijara and Ijaramuntahiya bi Tamlik. The Murabahah contract dominates the financing agreements on IMFI while Mudharabah, Ijarah, and Musyarakah contracts do not reach 30 percent of total financing (Mawardi et al., 2019). As a social institution, IMFIs also operate as 'Amil zakat, infaq, and Sadaqah. BMTs receive and distribute to those entitled. Besides, the BMTs can also be nadzir or managers of endowments (waqf).

Microfinance is a financing institution that provides many types of financial services, including microcredit. Microcredit is the type of loans given to customers with medium-scale business and is likely to have never been in touch with the world of banking. Customers of micro-loans often do not have anything to serve as collateral nor fixed income; the administrative requirements needed to access this micro-loan of tending to be more accessible. Customers from middle-class income are people that usually access this type of loans. Thus, developing microfinance institutions are a crucial strategy for poverty alleviation. The raised awareness about Islamic finance, which forbids usury, speculations and promotes economic activities based on the profit and loss sharing system helped the development of IMFIs (Tisdell \& Ahmad, 2018).

Muttaqien (2008) explains that the Islamic economic system does not only regulate the technical aspect to seek profit but also serves a fundamental philosophical outlook in the context of human economic activity. The presence of Islamic Micro Finance Institutions (in the form of KOPSYA, BMT, USPPS or KSPPS) is to be appreciated since these financial institutions can serve all segments of Indonesian society and assist the poor with financial supports.

According to Law No. 25 in 1992, the cooperative is a profit-oriented and business entity consisting of persons or legal entities with activities based on the principle of cooperation. Hendar \& Kusnadi (2005) explains several reasons why cooperatives become the backbone of the Indonesian economy, namely:

1) Cooperatives are a forum to accommodate the political message of a union that raises a common interest, helps itself together in improving the welfare of the community and increase economic productivities.

2) Cooperative is a form of business that not only accommodates but also maintains and strengthens the ideals and culture of the Indonesian nation. The country philosophy of teamwork and collective work (gotong royong) will flourish in cooperatives.

3) Cooperatives are the right place to foster small (indigenous) economic groups. 
4) Cooperatives are financial institutions with a social character.

5) Cooperatives can live in private business, in-state businesses and companies (State-Owned Enterprise) as well as in government agencies and educational institutions.

6) Cooperatives are an appropriate vehicle for realising the Pancasila Economy because of the fulfilment of the demands of togetherness and family principles. The cooperatives act as the centre of people's prosperity.

\section{Concepts Lender of the Last Resort}

The importance of lending from the last resort has been highlighted by many studies, starting from Bagehot (1873) to recent studies (Matsuoka, 2012). In the context of banks, the function of the lender of the last resort is to avoid financial system instability. The lending from the last resort or central bank is seen to be an effective solution and remedy in preventing severe bank panics (Okazaki, 2007). Its duties include accommodating liquidity assistance, given only to banks that suffer from possible liquidity shortage, and have the potential to trigger a severe systemic crisis. The goal is to avoid an early banking panic by appropriate insurance to provide high-powered emergency loans that are required to prevent detrimental and critical bank failures (Bordo, 2014; Franck \& Krausz, 2007; Garcia-de-Andoain et al., 2016;Goodhart \& Huang, 2005; Lastra, 1999;Ponce \& Rennert, 2015; Ratnovski, 2009).

According to Law No. 3 of 2004, the Central Bank (Bank Indonesia) is a state institution with authority to issue legal tender of a country. Bank Indonesia also formulates and performs monetary policy. It also regulates and maintains the flow of payment system, regulate, and supervise the banking system, and run the function of lender of last resort.

In implementing the duty of lender of last resort, Bank Indonesia provides credit or financing to banks undergoing critical short-term liquidity difficulties caused by the mismatch in fund management. The loans provided by Bank Indonesia to banks in-need is for a period of maximum 90 days. The requirement for receiving this loan is that the borrower is required to provide high-quality collateral; the collateral must be liquefied with the minimal collateral value equal to the loan amount.

\section{The urgency of Lender of the Last Resort}

Financial institutions such as Islamic Micro Finance Institutions (IMFI) are vulnerable to liquidity problems, the ability of financial institutions to meet all obligations. This liquidity problem is caused due to the mismatch period. Customers tend to deposit money in a relatively short period, while customers who apply for financing in Islamic microfinance institutions have a more extended period; thus, policy for Lender of the Last Resort (LOLR) is needed. LOLR is the key to tackle down the liquidity problem and is a useful tool in preventing crisis.

In principle, LoLR is divided into two, namely:

a) Normal LoLR loans given temporary to a financial institution with liquidity problems but do not have a systemic impact. The receiving 
Imron Mawardi, Tika Widiastuti, Muhammad Ubaidilah Al Mustofa, Ari

Prasetyo: Do Indonesian Islamic Microfinance Institutions Need Lender of the Last Resort?

loans should provide adequate collateral with a minimum value of the loans. Normal LoLR aims to keep the payment system and monetary stability remain smooth and stable.

b) LoLR crisis is a loan provided to a financial institution that is experiencing a shortage of liquidity and could cause systemic risk to the entire financial system. The potential systemic impact factor is the primary consideration in awarding LoLR to a crisis.

\section{Liquidity}

Brigham and Houston (2001) explain that the liquidity ratio shows the relationship between cash and other liquid assets with short-term liabilities. Syamsuddin (2004) argues that liquidity is the indicator to measure a financial intermediary's ability to fulfil all obligations at maturity, using available assets. A company can be liquid if the company can pay off its short-term financial obligations or long-term liabilities maturing during the year. Meanwhile, if a company cannot pay off their financial commitments, these companies are illiquid. Several factors to be considered in determining the company's liquidity include the amount of investment in fixed assets compared with the rest of the long-term funds, the volume of corporate activities, and the control of current assets Riyanto (2001).

Liquidity risk refers to the potential loss arising from financial institutions' inability to meet their financial obligations. The liquidity problem comes when many depositors call their funds at an inconvenient time for a large amount of liquidity. This causes fire sale of assets and negatively affecting the profitability of the financial intermediaries.

Liquidity risk affects the profitability of financial intermediaries (Arif \& Anees, 2012). This risk occurs when depositors collectively decide to withdraw their funds in an amount higher than the liquidity available in the financial institutions (Arif \& Anees, 2012; Hubbard, 2002). Besides, financial institutions experience a liquidity problem due to the mismatch between the nature of shortterm deposit to finance long-term business activities (Arif \& Anees, 2012; Dahir, Mahat, \& Ali, 2018; Du \& Dong, 2013; Giannotti, Gibilaro, \& Mattarocci, 2011; Mohammad, 2013). Naqvi (2015) stated if the total withdrawals of funds from a financial intermediary are high enough; even healthy and strong banks can eventually become bankrupt. These banks are forced to liquidate their assets at low prices prematurely. Such crises can severely disrupt the wealthiness of economic activity. Financial intermediaries' central position in the economy makes the adverse impact of financial disasters on economic activity cannot be overemphasised.

For the importance of this risk, liquidity risk management becomes an essential aspect of being conducted by every manager of financial intermediaries (Asongu, 2013). Bernstein, Hughson, \& Weidenmier (2010) argue that the lending facilities from the last resort or central banks help reduce the liquidity risk. 


\section{RESEARCH METHODS}

This qualitative study applies a case-study analysis. This study's subjects are Islamic Microfinance Institutions (IMFIs) in the form of Islamic cooperatives and Baitul Maal wat Tamwil (BMT) located in East Java Province. Thirty managers and co-managers from different IMFIs are the key informants.

East Java Province has consistently been the second-largest contributor to the National Gross Domestic Product after DKI Jakarta Province. East Java's Gross Regional Domestic Product was contributed by the manufacturing industry sector, large-scale trade sector, and agriculture, forestry, and fisheries sectors. Besides, three out of the ten biggest BMT in Indonesia are situated in the province of East Java, see table 1. These reasons highlighted the selection of East Java as the sample of the study.

Table 1 Top Ten BMTs (In Asset Value)

\begin{tabular}{ll}
\hline \multicolumn{1}{c}{ Name } & \multicolumn{1}{c}{ Province } \\
\hline 1. BMT Usaha Gabungan Terpadu Sidogiri & East Java \\
2. BMT Bina Umat Sejahtera & Central Java \\
3. BMT Maslahah Sidogiri & East Java \\
4. BMT Beringharjo & DI Yogyakarta \\
5. BMT Mandiri Sejahtera Gresik & East Java \\
6. KSPPS Benteng Mikro Indonesia & West Java \\
7. BMT Bahtera Pekalongan & Central Java \\
8. BMT Al-Ittihad & Riau \\
9. BMT Al-Idrisiyah, Tasikmalaya & West Java \\
10. BMT Bina Ihsanul Fikri & DI Yogyakarta \\
\hline
\end{tabular}

Source: Induk Koperasi Syariah (INKOPSYAH), 2019

Information and data are collected through several phases. The first is through a Focus Group Discussion (FGD) with The IMFI managers, the Department of Cooperative, academics and Microfin Indonesia, a Sharia Micro Finance Development Center. The main goal of FGD is to look for essential elements in determining the lender of last resort (LOLR) of IMFI. Further, the FGD aimed to obtain information on LOLR models which varied from one to another. Once the elements of the LOLR model is established, the next step is to conduct an in-depth interview with managers of IMFIs.

The content analysis method is applied to analyse the data and information obtained. The content analysis method is defined as a technique to draw essential conclusions by identifying specific characteristics of a message in an objective, systematic, and generalise manner (Holsti, 1969). This method analyses the whole discussion about the lender of last resort for IMFIs. The triangulation technique confirms and tests the reliability and integrity of the information.

\section{RESULTS AND DISCUSSION}

Islamic microfinance institutions (IMFI) operate like intermediary institutions, receiving deposits from the surplus unit and channelling it to the deficit unit. The average deposits received by the IMFI are short term deposits, while the financing 
Imron Mawardi, Tika Widiastuti, Muhammad Ubaidilah Al Mustofa, Ari

Prasetyo: Do Indonesian Islamic Microfinance Institutions Need Lender of the Last Resort?

facilities provided by the IMFI are long term financings. This naturally causes IMFI to face liquidity problems like intermediary institutions in general (Dahir, Mahat, and Ali, 2018). Liquidity problems with IMFI can harm IMFI and caused a systemic impact on the IMFI industry. Therefore, IMFI requires the presence of parties or the lender of the last resort mechanism.

To avoid the severe impact on the financial industry, the last resort's lender on IMFI can imitate banks. As financial intermediaries, the LOLR facilities are needed for IMFI and urged to be formed. "The IMFI operating system is the same as a bank. Therefore, it can mimic LOLR for the banking industries," said Aslichan Burhan, Executive Director of Pusat InkubasiBisnis Usaha Kecil (PINBUK).

This supported by Nyakdin, Chief of BMT PahlawanTulungagung. According to him, so far, groups of IMFI formed a non-formal LOLR institution to overcome liquidity problems that can occur at any time. "Management can indeed anticipate by looking at the historical withdrawal of members. For example, before Eid, the month of entering school, or before the harvest," he said.

Like banks, LOLR at IMFI must also provide loan facilities in routine and emergency conditions. Under normal circumstances, LOLR provides short-term loan facilities to overcome liquidity problems. In an emergency, LOLR can offer emergency loans. At banks, lenders of the last resort usually are given to banks that are not liquid but are solvent. In a crisis, systemic impacts are taken into consideration so that loans are given with costs can be charged to the government (Law No. 23 of 1999, which has been amended by Law No. 3 of 2004).

FGD participants agreed that all IMFI felt the urge to provide short-term loan facilities. The absence of LOLR facilities by IMFI makes IMFI find their way of dealing with the mismatch of deposit and financing that impacts the occurrence of liquidity problems. Several IMFI borrows from wealthy personages. "One of our members is a rich person who is willing to lend some liquidity when we are having difficulties," said Anas, chairman of KSPPS SunanDrajat, Lamongan. Several other IMFI managers also confirmed this. IMFI chose this method with small assets by asking wealthy individuals to become the foundation of short-term loans for IMFI.

Other managers stated that when IMFI needed funds to cover its lack of liquidity, they borrowed from other IMFIs. "Borrowing and Lending to fellow IMFIs is common. This is ta'awun (the Islamic concept of cooperation and assistance). If the needs are short-term, the contract is just debt," said Ali Hamdan, a manager who is also an IMFI supervisor from Microfin. Some IMFIs have prepared liquidity needs by requesting line facilities at Islamic banks. Stand by financing will be disbursed when IMFI needs funds expeditiously.

Many IMFIs borrow short-term financings with a qard or wadhiah yaddhamanah contracts. The funding needs are only for short time, ranging from one to seven days. However, according to Aslichan, if the needs are large enough or in a rather longer period, business contracts are used so that no one is harmed. "Usually, I use mudharabah, like mudharabah savings," he said. IMFI that provides funding is determined to place funds with IMFI who need funds. Compensation is given according to the profit-sharing portion that applies to 
IMFI, who need funds. For example, the average monthly revenue of IMFI A is 2 percent of deposits, and the profit-sharing portion of 50: 50. If IMFI B requires funds from IMFI A for 15 days, the revenue share paid by IMFI B is $50 \%$ x $2 \% \mathrm{x}$ $(15 / 30)=0.5 \%$.

The need for an institution that can provide short-term loans has been thought by IMFI facilitators such as Pinbuk. "We have initiated a secondary cooperative consisting of primary cooperatives. This secondary cooperative can provide loans to primary Islamic cooperatives," explained Aslichan. Ali Hamdan also confirms this from Microfin. This secondary cooperative functions to facilitate the linkage between IMFI in the form of a primary cooperative with a banking, government, or non-government organisation (NGO).

From the FGDs and interviews with IMFI managers, there are four lender models of last resort for IMFI. The first model of lender of last resort is to form a secondary cooperative. Several primary IMFIs established a formal guarantor institution in the form of a secondary cooperative. The members have equal duties and responsibilities toward others. The Primary Islamic cooperative that faces a liquidity problem can obtain liquidity support from the newly established secondary cooperative. Likewise, in the liquidity surplus period, the primary Islamic cooperative with excess cash can place funds on newly established secondary. Figure 1 shows the mechanism of forming a secondary cooperative, where two or more IMFIs unite and put funds to develop a legal lender of last resort. These IMFIs can then save funds in a secondary cooperative when they have excess liquidity and acquire liquidity when they need it.

Table 2. The Secondary Cooperatives

\begin{tabular}{lll}
\hline \multicolumn{1}{c}{ Name } & \multicolumn{1}{c}{ Province } \\
\hline 1. & Inkopsyah & Jakarta \\
2. & BMT Ventura & Jakarta \\
3. & Puskopsyah Solo & Central Java \\
4. & Puskopsyah Semarang & Central Java \\
5. & Puskopsyah & East Java \\
6. & Puskopsyah & South Sulawesi \\
7. & Puskopsyah Jambi & Jambi \\
8. & Bueka Assakinah & East Java \\
9. & Koperasi Sekunder Syariah Jawa Timur & East Java \\
10. & Koperasi Sekunder LDII Jawa Timur & East Java \\
\hline
\end{tabular}

Source: Induk Koperasi Syariah (INKOPSYAH), 2019

In the province of East Java, several BMTs and IMFIs form a secondary cooperative. Table 2 mentions several secondary cooperatives that have been established and are operating in Indonesia. Under the affiliation of Lembaga Dakwah Islam Indonesia (LDII), 40 BMTs and IMFIs establish secondary cooperation. BMT Pahlawan with 39 other BMTs in Tulungagung, Blitar, and Trenggalek districts form a secondary sharia cooperative named Pusat KoperasiSyariah or PUSKOPSYAH. Under Aisiyah Muhammadiyah East Java, 
Imron Mawardi, Tika Widiastuti, Muhammad Ubaidilah Al Mustofa, Ari

Prasetyo: Do Indonesian Islamic Microfinance Institutions Need Lender of the Last Resort?

40 BMTs also develop a secondary cooperative called Bueka As-Sakinah East Java.

The second solution to resolve the liquidity problem is to take financing supports from a sharia bank. In general, IMFIs are bankable entities that have assets, economics activities, and financial cashflows. Sharia banks may not be reluctant to provide the IMFIs back-up to solve the liquidity problems.Many IMFIs have a link agreement with sharia banks. This agreement aims to provide liquidity support and other purposes, such as to expand the reach of funding. BMT UGT Sidogiri, BMT MaslahahSidogiriPasuruan, BMT Mandiri Sejahtera Gresik are examples of several IMFIs with a link agreement to the sharia banks.

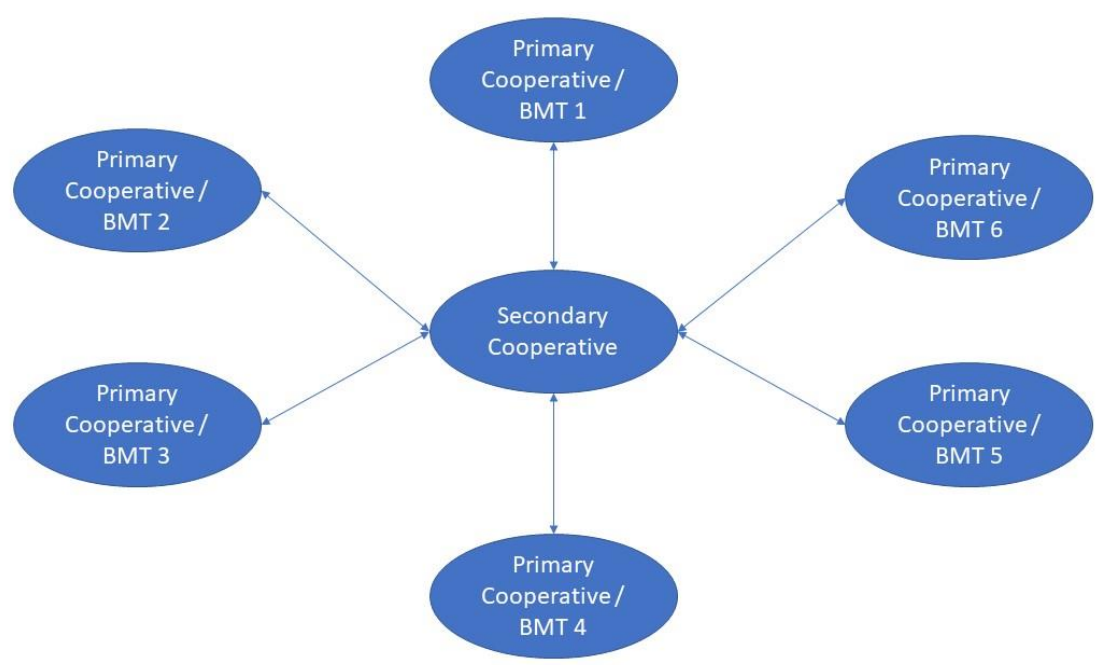

Figure 1. Forming a Secondary Cooperative

IMFIs in the same region can establish a mutual assistantship with others. Likewise, some IMFIs are affiliated in an organisation's ties, such as Nahdhatul Ulama, Muhammadiyah, and Lembaga Dakwah Islam Indonesia (LDII). IMFIs with organisational relationships usually establish non-formal associations to help each other in need, including an overwhelming lack of liquidity. If these IMFIs face liquidity problems, these organisations or financial institutions can provide financial supports.

Fourth, the IMFIs may have wealthy individuals' back-up that can provide financial support in need. IMFIs usually conduct this step with relatively small assets. Often, these wealthy people who offer to lend to IMFIs have business relationships, such as customers or executives' members. When IMFIs face liquidity problems, management borrows short-term funds from these wealthy personalities.

The best model of lender of the last resort for IMFIs is to establish the secondary cooperative, or the first model. The establishment of secondary 
cooperatives is built based on a spirit of taawun. Further, this concept resembles the concept of LOLR in the central bank when all banks in the economy place a percentage of third-party funds or deposits into the central bank's reserve or more commonly described as a required reserve. The central banks later use this reserve to provide liquidity assistance for commercial banks facing severe liquidity problems. A similar approach can be applied to the IMFIs, where a group of primary cooperatives establishes secondary cooperative. The primary cooperatives are obliged to place some percentage of third-party funds or deposits into the secondary cooperatives. These funds are then used by secondary cooperatives to provide liquidity assistance for those primary cooperatives that are facing severe liquidity problems. Further studies can develop the model of lending of last resort for IMFIs, Baitul Maal wat Tamwil, Islamic Cooperations at the international level, such as the concept of international lending of last resort developed by Lerrick \& Meltzer (2003), Corsetti et al. (2006) and Bastidon, Gilles, \& Huchet (2008).

\section{CONCLUSION}

As a financial intermediary, IMFIs face many risks, including liquidity problems. Most IMFIs solve liquidity problems by relying on customer deposits to overcome their liquidity. Another way is to form a link agreement with other financial institutions like banks and other IMFIs. IMFIs that cannot cope with their liquidity rely on ownership capital, from other secondary IMFI, asking for government support and borrow from Islamic bank loans. When the liquidity issued is solved, IMFIs conduct evaluation measures to optimise the internal process and reach maximum productivity. These measurements are useful in overcoming liquidity difficulties in the long run.

To solve the lack of liquidity, IMFIs create their own lender of last resort mechanisms. There are four models of IMFIs lender of last resort. First, the IMFIs established a formal guarantor institution in the form of a secondary cooperative. Second, IMFIs cooperates with Sharia bank by opening a stand-by loan which can be taken at any time when facing a liquidity problem. Third, IMFIs established the non-formal inter-financial institution relations. Fourth, to have an individual backup that can be borrowed at any time. However, the best model is to form a secondary cooperative. As the limitation of the study, this study builds a model of lending of last resort on IMFIs at a domestic level.

\section{REFERENCES}

Abbas, K., \& Shirazi, N. (2015). The key players' perception of the role of Islamic microfinance in poverty alleviation: The case of Pakistan. Journal of Islamic Accounting and Business Research, 6(2), 244-267. https://doi.org/10.1108/JIABR-06-2013-0017

Abdullah, R., \& Ismail, A. G. (2014). Al-Tawhid about the economic order of microfinance institutions. Humanomics, 30(4), 325-348. https://doi.org/10.1108/H-01-2014-0006 
Imron Mawardi, Tika Widiastuti, Muhammad Ubaidilah Al Mustofa, Ari

Prasetyo: Do Indonesian Islamic Microfinance Institutions Need Lender of the Last Resort?

Adnan, M. A., \&Ajija, S. R. (2015). The effectiveness of Baitul Maal wat Tamwil in reducing poverty The case of Indonesian Islamic Microfinance Institution Muhammad. Humanomics, 31(3), 354-371. https://doi.org/10.1108/H-042014-0037

Arif, A., \&Anees, A. N. (2012). Liquidity risk and performance of the banking system. Journal of Financial Regulation and Compliance, 20(2), 182-195. https://doi.org/10.1108/13581981211218342

Asongu, S. A. (2013). Post-crisis bank liquidity risk management disclosure. Qualitative Research in Financial Markets, 5(1), 65-84. https://doi.org/10.1108/17554171311308968

Bagehot, Walter, 1873. Lombard Street: A Description of the Money Market. London, H.S. King.

Bastidon, C., Gilles, P., \&Huchet, N. (2008). The international lender of last resort and selective bail-out. Emerging Markets Review, 9(2), 144-152. https://doi.org/10.1016/j.ememar.2008.02.004

Berhane, G., \&Gardebroek, C. (2011). Does microfinance reduce rural poverty? Evidence-based on household panel data from northern Ethiopia. American Journal of Agricultural Economics, 93(1), 43-55. https://doi.org/10.1093/ajae/aaq126

Bernstein, A., Hughson, E., \&Weidenmier, M. D. (2010). Identifying the effects of a lender of last resort on financial markets: Lessons from the founding of the fed. Journal of Financial Economics, 98(1), 40-53. https://doi.org/10.1016/j.jfineco.2010.04.001

Bordo, M. D. (2014). Rules for a lender of last resort: An historical perspective. Journal of Economic Dynamics and Control, 49, 126-134. https://doi.org/10.1016/j.jedc.2014.09.023

Brigham, Eugene and Houston, Joel F. 2001. Dasar DasarManajemenKeuangan, Buku 2. Jakarta: SalembaEmpat.

Corsetti, G., Guimarães, B., \& Roubini, N. (2006). International lending of last resort and moral hazard: A model of IMF's catalytic finance. Journal of Monetary Economics, 53(3), 441-471. https://doi.org/10.1016/j.jmoneco.2005.03.008

Dahir, A. M., Mahat, F. B., \& Ali, N. A. Bin. (2018). Funding liquidity risk and bank risk-taking in BRICS countries: An application of system GMM approach. International Journal of Emerging Markets, 13(1), 231-248. https://doi.org/10.1108/IJoEM-03-2017-0086

Du, W., \& Dong, G. (2013). Lecture Notes in Electrical Engineering: Preface. Lecture Notes in Electrical Engineering, 204 LNEE. https://doi.org/10.1007/978-1-4471-4802-9

Ensuring Financial Stability in Countries with Islamic Banking. (2017). In International Monetary Fund. Retrieved from http://www.imf.org/ /media/Files/Publications/PP/PP-Ensuring-FinancialStability-in-Countries-with-Islamic-Banking.ashx 
Fianto, B. A., Gan, C., Hu, B., \&Roudaki, J. (2018). Equity financing and debtbased financing: Evidence from Islamic microfinance institutions in Indonesia. Pacific Basin Finance Journal, 52(September 2017), 163-172. https://doi.org/10.1016/j.pacfin.2017.09.010

Fianto, B. A., Maulida, H., \& Laila, N. (2019). Determining factors of nonperforming financing in Islamic microfinance institutions. Heliyon, 5(8). https://doi.org/10.1016/j.heliyon.2019.e02301

Franck, R., \&Krausz, M. (2007). Liquidity risk and bank portfolio allocation. International Review of Economics and Finance, 16(1), 60-77. https://doi.org/10.1016/j.iref.2004.09.007

Garcia-de-Andoain, C., Heider, F., Hoerova, M., \&Manganelli, S. (2016). Lending-of-last-resort is as lending-of-last-resort does: Central bank liquidity provision and interbank market functioning in the euro area. Journal of Financial Intermediation, 28, 32-47. https://doi.org/10.1016/j.jfi.2016.01.003

Giannotti, C., Gibilaro, L., \&Mattarocci, G. (2011). Liquidity risk exposure for specialised and unspecialised real estate banks: Evidence from the Italian market. Journal of Property Investment \& Finance, 29(2), 98-114. https://doi.org/10.1108/14635781111112756

Goodhart, C. A. E., \& Huang, H. (2005). The lender of last resort. Journal of Banking and $\quad$ Finance, 1059-1082. https://doi.org/10.1016/j.jbankfin.2003.11.003

Hadisumarto, W. B. M. C., \& Ismail, A. G. B. (2010). Improving the effectiveness of Islamic micro-financing: Learning from BMT experience. Humanomics, 26(1), 65-75. https://doi.org/10.1108/08288661011025002

Hassan, A., \& Saleem, S. (2017). An Islamic microfinance business model in Bangladesh: Its role in alleviation of poverty and socio-economic well-being of women. Humanomics, 33(1), 15-37. https://doi.org/10.1108/H-08-20160066

Hassan, M. K., Aliyu, S., Huda, M., \& Rashid, M. (2019). A survey on Islamic Finance and accounting standards. Borsa Istanbul Review, 19, S1-S13. https://doi.org/10.1016/j.bir.2019.07.006

Hendar\&Kusnadi, 2005. EkonomiKoperasi (UntukPerguruan Tinggi) EdisiKedua, Lembaga PenerbitFakultasEkonomiUniversitas Indonesia. Jakarta

Holsti, Ole R. 1969. Content Analysis for the Social Science and Humanities.Reading, Massachusetts: Addison - Westley Pub lishing.

Hubbard, G.R. (2002), Money, The Financial System, and the Economy. New Jersey: The Addison Wesley Series in Economics, Person Education Inc.

Lastra, R. M. (1999). Central banks as lenders of last resort: Lessons from the Asian contagion. Journal of Financial Regulation and Compliance, 7(3), 234-242. https://doi.org/10.1108/eb025011

Lerrick, A., \& Meltzer, A. H. (2003). Blueprint for an international lender of last resort. Journal of Monetary Economics, 50(September 2002), 289-303. 
Imron Mawardi, Tika Widiastuti, Muhammad Ubaidilah Al Mustofa, Ari 249 Prasetyo: Do Indonesian Islamic Microfinance Institutions Need Lender of the Last Resort?

Littlefield, E., Morduch, J., \& Hashemi, S. (2003). Is Microfinance an Effective Strategy to Reach the Millennium Development Goals? In CGAP (Vol. 24). Retrieved from http://ifmr.ac.in/cmf/wp-content/uploads/2007/06/mf-mdgsmorduch.pdf

Matsuoka, T. (2012). Journal of Economic Dynamics \& Control Imperfect interbank markets and the lender of last resort. Journal of Economic Dynamics and Control, 36(11), 1673-1687. https://doi.org/10.1016/j.jedc.2012.05.003

Mawardi, I., Sukmaningrum, P. S., Widiastuti, T., \& Al Mustofa, M. U. (2019). Optimum financing portfolio of islamic microfinance institutions : Indonesia case. Utopía y Praxis Latinoamericana, 24 (EXTRA 5), 268-274.

Mohammad, S. (2013). Liquidity Risk Management in Islamic Banks: A Survey. Afro Eurasian Studies, 1(2), 215-230. Retrieved from http://www.afroeurasianstudies.net/dosyalar/site_resim/veri/1513272.pdf

Muttaqien. 2008. Aspek Legal Lembaga Keuangan Syariah Bank, LKM, Asuransi, dan Reasuransi. Yogyakarta: SafiriaInsania Press.

Naqvi, H. (2015). Banking crises and the lender of last resort: How crucial is the role of information? Journal of Banking and Finance, 54, 20-29. https://doi.org/10.1016/j.jbankfin.2015.01.004

Okazaki, T. (2007). Micro-aspects of monetary policy: Lender of Last Resort and selection of banks in pre-war Japan. Explorations in Economic History, 44, 657-679. https://doi.org/10.1016/j.eeh.2006.11.002

Ponce, J., \&Rennert, M. (2015). Systemic banks and the lender of last resort. Journal of Banking and Finance, 50, 286-297. https://doi.org/10.1016/j.jbankfin.2014.01.002

Rahman, R. A., \& Dean, F. (2013). Challenges and solutions in Islamic microfinance. Humanomics, 29(4), 293-306. https://doi.org/10.1108/H-062012-0013

Ratnovski, L. (2009). Bank liquidity regulation and the lender of last resort. Journal of Financial Intermediation, 18(4), 541-558. https://doi.org/10.1016/j.jfi.2007.08.001

Riyanto, Bambang. 2001. Dasar-dasarPembelanjaan Perusahaan. BPFE, Yogyakarta.

Syamsudin, Lukman, 2004. ManajemenKeuangan. Jakarta: Penerbit Raja GrafindoPersada.

Tisdell, C., \& Ahmad, S. (2018). Microfinance: economics and ethics. International Journal of Ethics and Systems, 34(3), 372-392. https://doi.org/10.1108/IJOES-02-2018-0028

Wardiwiyono, S. (2012). Internal control system for Islamic micro financing: An exploratory study of Baitul Maal wat Tamwil in the City of Yogyakarta Indonesia. International Journal of Islamic and Middle Eastern Finance and Management, 5(4), 340-352. https://doi.org/10.1108/17538391211282836 